\title{
PENDAMPINGAN MANAJEMEN USAHA DAN PEMASARAN PRODUK PENGRAJIN PANDAI BESI DI DESA PAMBOBORANG KECAMATAN BANGGAE KABUPATEN MAJENE PROVINSI SULAWESI BARAT
}

\author{
Arifhan Ady Dj ${ }^{*}$ \\ Wahyu Maulid Adha ${ }^{2}$ \\ Akhdiari Harpa $\mathrm{Dj}^{3}$ \\ 1,2Fakultas Ekonomi Universitas Sulawesi Barat, Indonesia \\ ${ }^{3}$ Fakultas Ilmu Sosial dan Ilmu Politik Universitas Sulawesi Barat, Indonesia \\ arifhanadydj@unsulbar.ac.id ${ }^{*}$ ) \\ wahyu.adha@gmail.com ${ }^{2}$ \\ akhdiari.harpadj@gmail.com ${ }^{3)}$
}

Kata Kunci:
[Manajemen usaha,
Strategi
pemasaran]

Kata Kunci:

Abstrak: Desa Pamboborang Kecamaatan Banggae Kabupaten Majene terkenal dengan usaha-usaha ekonomi produktif. Salah satu usaha ekonomi produktif yang menonjol di desa ini adalah usaha "Kappung Kowiq" (kampung pandai besi) karena sejak zaman dahulu sampai sekarang di kampung ini mayoritas masyarakatnya merupakan pandai besi. Dalam menjalankan usahanya, Kelompok Usaha Bersama (KUB) Pandai Besi Indo Banua menghadapi berbagai masalah di antaranya adalah proses produksi di kerjakan dengan menggunakan alat-alat yang sangat sederhana sebagai teknologinya. Tata kelola sistem manajemen usaha termasuk di dalamnya aspek-aspek manajemen usaha yang meliputi perencanaan usaha, pengorganisasian, implementasi, pengelolaan manajemen keuangan yang masih dikelola secara sederhana, bauran pemasaran dalam memasarkan produk masih menggunakan cara pemasaran dari mulut ke mulut. Oleh karena Pengabdian kepada masyarakat ini bertujuan meningkatkan pemahaman dan pengetahuan mitra tentang aspek-aspek manajemen usaha yang meliputi perencanaan usaha, pengorganisasian, implementasi, manajemen keuangan serta pemahaman kelompok tentang strategi pemasaran. Pendekatan pemberdayaan yang dilakukan untuk mecapai tujuan adalah melalui tahap persiapan, assesment, Perencanaan dan alternatif kegiatan, Formulasi/rencana aksi, pelaksanaan kegiatan pelatihan, dan evaluasi.

Published by:

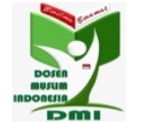

Copyright (C) 2021 The Author(s)

This article is licensed under CC BY 4.0 License (cc) $\mathrm{BY}$ 


\section{Pendahuluan}

Desa Pamboborang Kecamatan Banggae Kabupaten Majene terkenal dengan usaha-usaha ekonomi produktif alternatif. Salah satu usaha ekonomi produktif yang menonjol di desa ini adalah usaha "Kappung Kowiq" (kampung pandai besi), karena sejak zaman dahulu sampai sekarang di kampung ini mayoritas masyarakatnya merupakan pandai besi. Sebagai sentra kegiatan ekonomi kreatif pandai besi di Kabupaten Majene, saat ini terdapat 33 kelompok pengrajin pandai besi yang tersebar pada empat dusun dari enam dusun yang ada di Desa Pamboborang, namun yang rutin memproduksi kerajinan logam hanya tersisa 22 kelompok, sisanya hanya akan berproduksi jika menerima pesanan, di tangan pengrajin pandai besi desa ini, berbagai produk kerajinan logam dihasilkan di antaranya sabit, cangkul, parang, keris, badik, sabit, pisau dapur dan lain sebagainya.

Kelompok Usaha Bersama Indo Banua sebagai salah satu pengrajin pandai besi yang terdapat di desa Pamboborang Kecamatan Banggae Kabupaten Majene. Dalam perihal memproduksi kerajinan logam, seperti mayoritas industri kecil yang ada, industri kerajinan pandai di desa pamboborang mengalami berbagai hambatan serta permasalahan. proses pembuatan dan produksi masih dikerjakan dengan memakai alatalat yang sangat masih sangat sederhana.( Putra,dkk, 2018). Begitupula dengan aspekaspek manajemen usaha yang mencakup perencanaan usaha, pengorganisasian, implementasi, dan pengendalian usaha jarang menjadi perhatian para pelaku usaha pengrajin pandai besi, manajemen keuangan yang sesungguhnya sangat berarti dalam menghitung keuntungan usaha serta omset yang di dapat juga luput dari atensi para pelaku usaha.

Permasalahan berikutnya adalah strategi dalam memasarkan produk, para pengrajin masih menggunakan cara pemasaran dari mulut ke mulut, melalui kenalan dan belum menggunakan perangkat alat pemasaran praktis yang dapat dikendalikan untuk mengetahui apa yang di inginkan pasar (Kurniawan, dkk, 2015). Masalah lainnya yakni minimnya variasi jasa yang ditawarkan (Abdurahman, 2015).

Walaupun sampai saat ini terdapat banyak kendala dalam dalam mengembangkan usaha, kerajinan pandai besi yang ada di Desa Pamboborang. Usaha kerajinan pandai besi yang ada di Desa Pamboborang masih mempunyai prospek dalam membantu meningkatkan pendapatan bagi masyarakat. Oleh karena itu diperlukan penanganan dalam pengelolaan usaha industri kecil menengah pengrajin pandai besi, sehingga dapat memberikan kontribusi terhadap masyarakat pengrajin.

\section{Metode Pelaksanaan}

\section{Lokasi Kegiataan}

Kegiatan pengabdian dilaksanakan dari bulan Juni-Agustus 2020. Pada kegiatan ini terdapat 15 peserta yang hadir, yang semuanya adalah anggota Kelompok Usaha Bersama Indo Banua. Pada kegiatan ini, tim pengabdi bertindak sebagai penyuluh pada kelompok pengrajin pandai besi yakni kelompok usaha bersama indo banua sebagai peserta kegiatan penyuluhan dan pelatihan.

\section{Bahan dan Alat}

Bahan dan alat yang digunakan dalam pelatihan ini adalah: 
1. LCD dan laptop yang akan digunakan oleh tim pemateri dalam hali ini tim pengabdian kepada masyarakat untuk memberikan materi dan penyuluhan kepada kelompok mitra;

2. Spanduk bertuliskan tema kegiatan dan waktu pelaksanaan yang dilaksanakan oleh tim pengabdi kepada mitra;

3. Alat tulis menulis (ATK) yang digunakan oleh mitra dan tim pengabdi.

\section{Metode penyelesaian masalah}

Sesuai dengan permasalahan mitra yang telah dirumuskan sebelumnya, pendekatan yang dilakukan bagi realisasi PKM ini adalah model pemberdayaan dengan tahapan sebagai berikut : (1) Persiapan, (2) Assessment, (3) Perencanaan dan alternatif kegiatan, (4) Formulasi /rencana aksi, (5) Pelaksanaan Kegiatan pelatihan, (6) Evaluasi program. Program PKM ini merupakan program pemberdayaan kepada kelompok Usaha Bersama Indo Banua melalui kegiatan, pelatihan manajemen usaha dan pemasaran yang menitik beratkan pada pengembangan usaha. Metode pelaksanaan yang akan dilaksanakan : (1) pelatihan manajemen usaha bagi kelompok mitra, (2) pelatihan pengelolaan keuangan bagi kelompok mitra (3) pelatihan manajemen pemasaran (4) pendampingan.

\section{Rencana Kegiatan}

Pendekatan dalam Kegiatan PKM ini dilaksanakan secara Button-up dimana pada tahap perencanaan, tindakan yang dilakukan adalah mengetahui dan menjawab semua permasalahan mitra dalam hal ini kelompok usaha bersama indo banua secara partsipasif. Adapun tahapan pelaksanaan adalah :

1. Idetifikasi potensi, tim PKM selaku pelaksana bersama mitra mengindentifikasi potensi yang dimiliki oleh mitra berupa keahlian dan jumlah tenaga kerja, bahan baku, manajemen usaha, pasar, lingkungan internal dan eksternal

2. Menganalisis kebutuhan mitra dan memberi solusi dari masalah yang dihadapi,

3. Rencana Kerja yang akan dilakukan meliputi persiapan kegiatan dan waktu pelaksanaan

4. Pelatihan

Untuk mendukung kegiatan pelatihan yang akan dilaksanakan dalam dua tahapan kegiatan, maka substansi kegitan pelatihan meliputi :

a) Kegiatan Pelatihan manajemen usaha meliputi perencanaan usaha, serta pengelolaan manajemen keuangan :

- Mitra diperkenalkan tentang manajemen usaha didalamnya dijelaskan tentang materi pengertian perencanaan usaha, pengorganisasian, implementasi, dan pengendalian,

- Mitra diperkenalkan tentang manajemen keuangan didalamnya dijelaskan tentang materi pembuatan dan pembentukan laporan keuangan yang sederhana dalam bisnis industri/ UKM rumah tangga

b) Kegiatan Pelatihan strategi pemasaran dan permodalan meliputi :

- Mitra diperkenalkan tentang manajemen pemasaran di dalamnya dijelaskan tentang materi strategi pemasaran diawali dari identifikasi kebutuhan konsumen/pasar, pemilihan target konsumen/pasar, 
identifikasi pesaing, sarana untuk bersaing, penggunaan media elektronik untuk pemasaran

- Pelatihan penyusuna proposal pendanaan

- Monitoring dan evaluasi untuk semua program sesuai target luaran

\section{Partisipasi mitra}

Suksesnya program tidak terlepas daripada partsipasi mitra yang menjadi tolak ukur keberhasilan, Muhsin (2018). Mitra berperan aktif mengikuti kegiatan pelaksanaan penyuluhan dan pelatihan tentang manajemen usaha dan manajemen pemasaran. Peran aktif kelompok mitra, dalam hal ini KUB Indo Banua selama mengikuti kegiatan, diharapkan bisa mengenali dan tahu, mencari solusi atas berbagai permasalahan yang dialami oleh kelompok selama ini

\section{Hasil dan Pembahasan}

Tahapan kegiatan PKM Program pengabdian kepada masyarakat meliputi survei awal ke lapangan sebelum kegiatan penyuluhan dan pelatihan diadakan, survei awal dilakukan kepada kelompok binaan Kub Indo Banua Desa Pamboborang Kecamatan Banggae Kabupaten Majene

Pelaksanaan rapat dilakukan guna membahas persiapan dan jadwal pelaksanaan program yang akan diadakan kepada kelompok binaan ini KUB Indo Banua pada tanggal 19 september 2020. Persiapan program pelatihan dilakukan oleh tim pengabdian pada masyarakat dengan meyiapkan bahan yang akan digunakan pada saat pelatihan, diantaranya, LCD, Materi Powerpoint dan modul. Materi pelatihan meliputi manajemen usaha, manajemen pemasaran.

Setelah dilakukan kegiatan pelatihan/penyuluhan tentang materi manajemen usaha didalamnya dijelaskan tentang materi pengertian perencanaan usaha, pengorganisasian, implementasi, dan pengendalian, materi tentang manajemen keuangan di dalamnya dijelaskan tentang materi pembuatan dan pembentukan laporan keuangan yang sederhana dalam bisnis industri/UKM rumah tangga, serta materi strategi pemasaran di dalamnya dijelaskan tentang materi strategi pemasaran diawali dari identifikasi kebutuhan konsumen/pasar, pemilihan target konsumen/pasar, identifikasi pesaing, sarana untuk bersaing, penggunaan media elektronik untuk pemasaran, terjadi peningkatan pengetahuan dan keterampilan para anggota KUB indo Banua Desa Pamboborang Kecamatan Banggae Kabupaten Majene, tentang pentingnya manajemen usaha, praktek pembukuan sederhana dan strategi pemasaran. Hal ini dapat dilihat dari perbandingan hasil kuisioner awal dan akhir dari 15 anggota pengrajin logam KUB indo Banua Desa Pamboborang Kecamatan Banggae Kabupaten Majene.

Tabel 1. Persentase Pengetahuan anggota pengrajin pandai besi Kub Indo Banua Desa Pamboborang Kecamatan Banggae Kabupaten Majene sebelum mengikuti pelatihan dan pendampingan

\begin{tabular}{lcc}
\hline $\begin{array}{l}\text { Pemahaman tentang manajemen } \\
\text { usaha dan pemasaran }\end{array}$ & frekuensi & Persentase (\%) \\
\hline Sudah paham & 4 & 26,66 \\
Belum paham & 11 & 73,34 \\
Jumlah & 15 & 100 \\
\hline
\end{tabular}


Pada kuisioner awal diperoleh skor 26,66 \% (tabel1) dari kelompok mitra binaan Kub Indo Banua Mitra yang sudah paham dan mengerti tentang manajemen usaha, pembuatan laporan keuangan dan dan materi pemasaran meliputi, strategi pemsaaran konsumen/pasar, pemilihan target konsumen/pasar, identifikasi pesaing, sarana untuk bersaing, penggunaan media elektronik untuk pemasaran. Rendahnya pengetahuan dan pemahaman pengrajin pandai besi selama ini disebabkan oleh karena kurangnya pendampingan, pembinaan selama mereka menekuni usaha tersebut.

Tabel 2. Persentase Pengetahuan anggota pengrajin pandai besi Kub Indo Banua Desa Pamboborang Kecamatan Banggae Kabupaten Majene setelah mengikuti pelatihan dan pendampingan

\begin{tabular}{lcc}
\hline Pemahaman tentang manajemen & frekuensi & Persentase (\%) \\
usaha dan pemasaran & & 80,00 \\
\hline Sudah paham & 12 & 20,00 \\
Belum paham & 3 & 100 \\
Jumlah & 15 & Sedangkan pada kusioner akhir terjadi peningkatan skor menjadi $80,00 \%$
\end{tabular}
(Tabel2). Berarti terjadi peningkatan pemahaman pengrajin pandai besi terhadap materi pelatihan manajemen usaha, pembuatan laporan keuangan dan materi pemasaran meliputi, strategi pemasaran konsumen/pasar, pemilihan target konsumen/pasar, identifikasi pesaing, sarana untuk bersaing, penggunaan media elektronik untuk pemasaran yang telah disampaikan.
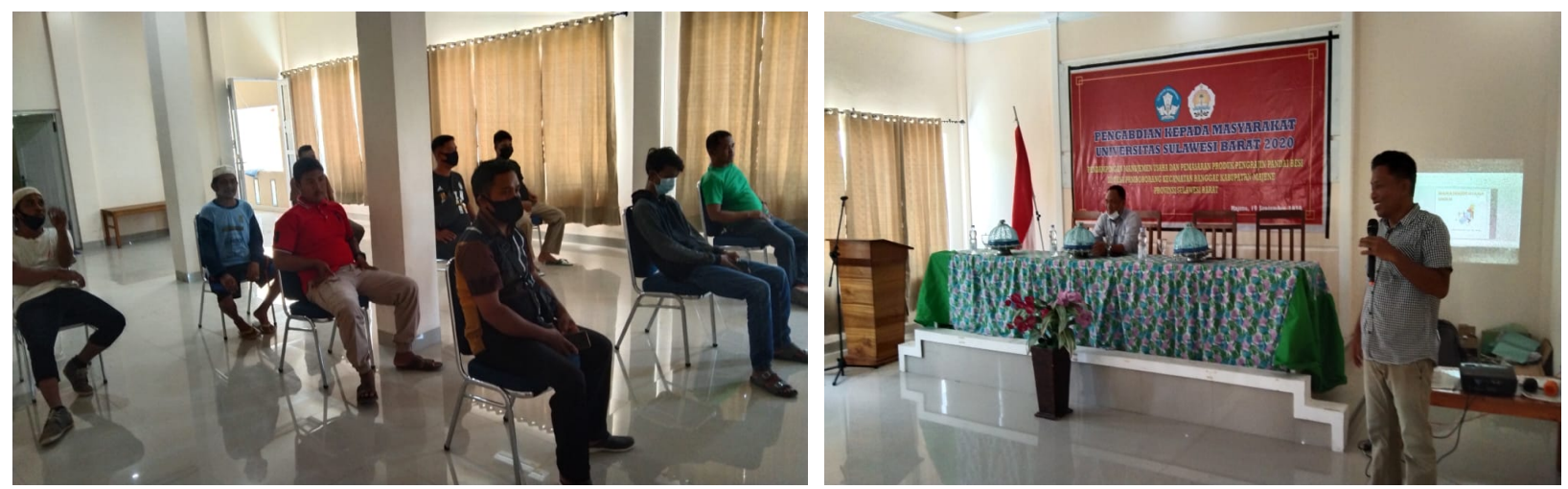

Gambar 1. Foto antusiasme peserta sosialisasi Gambar 2. Foto Penyampaian Mater
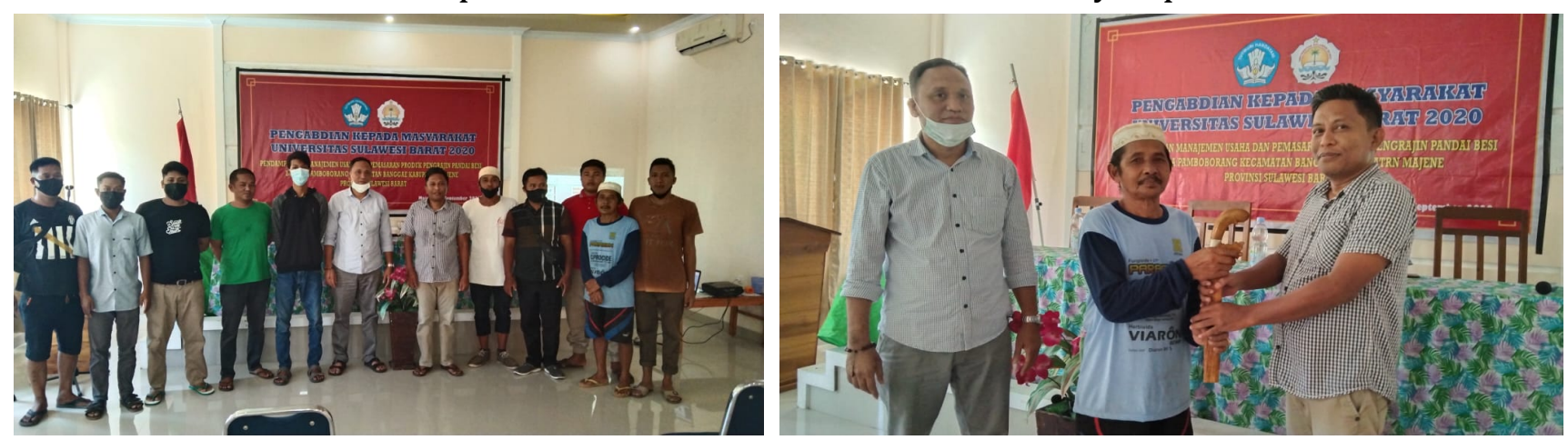

Gambar 3. Foto Bersama PKM

Gambar 4. Foto Penyerahan cindera mata 


\section{Kesimpulan}

Berdasarkan kegiatan yang telah dilaksanakan oleh Tim PKM pada Kelompok Usaha Bersama KUB Pandai Besi “ Indo Banua " di Desa Pamboborang Kecamatan Banggae Kabupaten Majene Provinsi Sulawesi Barat, disimpulkan :

1. Pelaksanaan sosialisasi manajemen usaha dan manajemen pengelolaan keuangan dalam kegiatan usaha telah memenuhi luaran yang di targetkan, yaitu terjadi pemahaman bagaimana mengelola manajemen usaha yang baik, dimulai dari proses perencanakan, proses evaluasi untuk pencapaian sasaran, serta pengelolaan manajemen pengelolaan keuangan yang terdiri dari sumber dana, Perencanaan, penggunaan dana serta Pengawasan/pengendalian keuangan

2. Sosialisasi mengenai pengenalan mekanisme strategi pemasaran guna peningkatan penjualan telah mencapai target luaran. Setelah dilakukan sosialisasi, peserta menjadi paham dan dapat mengidentifikasi kebutuhan konsumen, menetukan target potensial, mengidentifikasi pesaing, memilih sarana bersaing dan memilih penggunaan media dalam promosi. Selanjutnya, peserta juga telah menerapkan media elektronik sebagai saran promosi agar lebih menjangkau pasar yang lebih luas. Dengan diberikannya keseluruhan sosialisasi tersebut kepada Kelompok Usaha Bersama (KUB) Pandai Besi “ Indo Banua”, diharapkan dapat dapat berkembang lebih baik lagi di masa mendatang

\section{Ucapan Terimakasih}

Universitas Sulawesi Barat yang telah memberikan Bantuan dana DIPA Tahun 2020 kepada kami selaku dosen untuk melakukan kegiatan Tri Darma Perguruan Tinggi.

\section{Referensi}

Andriani, Dewi. (2021). Awas! Jangan Tergiur, Fenomena Munculnya Influencer Saham. Bisnis.com. Retrieved from https://finansial.bisnis.com/read/20210109/55/1340828/awas-jangan-tergiurfenomena-munculnya-influencer-saham

Abdurahman Nana Herdiana. 2015. Manajemen Strategi Pemasaran. Pusaka Setia: Bandung

Kurniawan, \& Luthfi. (2015). Proses City Branding Yogyakarta (Studi Kualitatif Pada Merek “Jogja Istimewa”). Jurnal Ilmiah Universitas Bakrie, 3(3).

Muhsin, M. (2018). Peningkatan Kualitas Pembelajaran Bahasa Inggris Melalui Pelatihan Pengembangan Modul di Madrasah Tsanawiyah Kabupaten Sigi Sulteng. Jurnal Dedikasi Masyarakat, 1(2), 79-89.

Putra, T. D., \& Budiantono, B. (2018, October). Peningkatan Mutu Produk Kerajinan Rotan Dengan Sentuhan Teknologi Kota Malang. In Conference on Innovation and Application of Science and Technology (CIASTECH) (Vol. 1, No. 1, pp. 345352)Intan, Novita dan Zuraya Nadia. (2021). Masa Pandemi, OJK Catat Pinjaman Online Capai $\mathrm{Rp} 146,25$ T. Republika Indonesia. Retrieved from 
Jurnal Abdimas Indonesia

https://republika.co.id/berita/qmhr8k383/masa-pandemi-ojk-catat-pinjamanonline-capai-rp-14625-t. 